Having myself read through much of the Higher Nonsense in getting material for my own books, I must admire Godwin's stamina in wading through the vast quantities listed in his bibliography. His attitude towards the prophets of Hidden Wisdom and Secret Masters is admirably fair and nonjudgemental, albeit when considered en masse these colourful and riotously contradictory doctrines merely lend proof to Bertrand Russell's statement that most people, if you shout "Two and two make five!" at them long and loudly enough, will come to believe that two and two do, after all, make five.

As to whether the leaders of the countless occult and magical cults believe their own claims, who knows? We do not yet have a mind-reading machine, and Godwin does not address the topic. Cyrus Teed probably believed his own line. Contrariwise, Blavatsky seems to have been altogether cynical. Finding that she could make people believe that two and two make five, she exploited this gift to the hilt, as the most effective way open to her to make a living.

In one of her impulsively candid moods, Blavatsky told the Unitarian preacher Conway: "It's all glamour. People think they see what they don't see; that's all there is to it." The Russian journalist Solovyoff (or Solovëv) quoted her thus: "What is one to do when, in order to rule men, you must deceive them, when, in order to catch them and make them pursue whatever it may be, it is necessary to promise and show them toys?" Some purveyors of the Higher Nonsense may have begun their leadership from pure self-interest, but as time passed they came to believe their own pitch. (This may have been the case with the late L. Ron Hubbard of Scientology fame.)

Although Godwin seems not to be taken in by the prophets of Hidden Wisdom and Secret Masters, his attitude towards "materialistic science" is hardly more favourable. He accuses scientists of "brainwashing" the young with their doctrines of boundless "progress". This is confusing the scientific beliefs to which accumulating evidence pushes scientists with their beliefs on nonscientific (social, moral or cultural) matters. There is no hard-and-fast connection between the two sets of convictions. Thus the great ethologist Konrad Lorenz revealed Nazi tendencies. Godwin wants to hang on to the "realities and truths that stand inviolate", such as those attributed to Christianity.

When much younger, I rejoiced in freedom from religious dogma, thinking: wouldn't it be fine if everyone adopted my own hard-nosed, sceptical, materialistic, nonsupernatural, scientific view? Now, having seen the results of trying to run an empire (the Soviet Union) on the basis of a purely secular, nontheistic philosophy, I am not sure that masses of men can manage their affairs without supernatural beliefs about, for example, rewards and punishments after death, or promotion and downgrading in one's next incarnation. So let Godwin hang on to his Christianity - if he can - even though I might not accept his arguments myself.

The work is a remarkably comprehensive coverage of the pseudoscientific field in recent centuries, well written and knowledgeable. If the author wanders off the boundaries of polar geomythology, that is inevitable in trying to make sense of such hazy, amorphous concepts. It is like trying to measure a cloud with a surveyor's tape. Nor is the subject trivial. Sixty years ago, many wellinformed people dismissed the Aryanrace cult as crackpot nonsense, and we know that use was made of the myth.

L. Sprague de Camp is at 3453 Hearst Castle Way, Plano, Texas 75025-3605, USA.

\section{Out of the bell jar}

\section{Hugh Freeman}

Touched With Fire: Manic-Depressive IIIness and the Artistic Temperament. By Kay Redfield Jamison. Free Press (Macmillan Inc., New York): 1993. Pp. 370. $\$ 24.95$.

"ONE of the oldest and most persistent of cultural notions", says Kay Jamison, is that of a possible link between madness and genius, even though many of the outstandingly creative have always appeared to be healthy and well balanced. In her view, confusion about the meaning of 'madness', together with ignorance particularly of the nature of manic-depressive (or affective) illness, has been responsible for most of the controversy around this theme. It has also tended to fall between two academic stools - psychiatric research, which is mainly biological, having little interest in the experience of writers and artists, and scholars of creativity fruitlessly pursuing a connection with schizophrenia. Jamison, though, was not only the co-author of one of the standard works on affective disorder, but has personally investigated a large British sample of artistically creative people. With these unique qualifications, what has she made of the 'mad genius' notion?

Her declared purpose is "to make a literary, biographical and scientific argument for a compelling association between two temperaments - the artistic and the manic-depressive - and their relationship to the rhythms of the natural world". At the same time, she warns that labelling anyone who is unusually creative or eccentric with this diagnosis "both diminishes the notion of individuality within the arts and trivialises a very serious illness". Nor are most people who have affective disorder unusually creative. For a start, though, there have to be clear distinctions between affective psychosis (at the extreme end of the spectrum), episodes of major depression (or, more rarely, of mania) and fluctuations of mood. If these disorders are confused, as they often are, it becomes impossible to compare any one set of data about them with another.

Should anyone be disinclined to take manic-depressive illness seriously, Jamison points out that, if untreated, its mortality - now mainly through suicide - is higher than that for many types of heart disease; out of a long list of poets, a staggering 18 per cent had taken their own lives. There may also be disguised cases: Byron's involvement in the Greek War of Independence may in fact have been a way of ensuring his own death. The purpose of knowing this, however, is not just as an exploration of psychopathology, but to understand the man and his work more deeply. Tabulating what is known about 37 British and Irish poets born between 1705 and 1805 , Jamison records that no fewer than 30 of them had evidence of significant affective disorder.

While all this information is impressive, it involves what epidemiologists call the 'floating numerator' - a problem which Jamison does not deny. Not only is the denominator of 'poets' very difficult to define, but literary scholarship has resulted in our knowing much more about the famous than about the unknown, which could bias the evidence. An alternative approach, though, comes from affective disorder being "the most genetic of the major psychiatric illnesses", providing what Jamison describes as "the constitutional core of a determining temperament". Although the genetic mechanisms are still largely unknown, studies of separated twins provide strong support for the illness being familial, with many unaffected relatives also showing cyclical swings of mood. What is particularly relevant here is that unusual creativity and other abilities may run prominently through the same families.

So the disorder is "paradoxically advantageous and yet destructive". Its most characterisic feature is a cycle of fluctuations in mood, energy, sleep and creativity in those who have the gift for it. Quite recently, 'seasonal affective disorder', with depression related to the darkness of winter, has been found to be relatively common, and the incidence of suicide peaks in spring and autumn. 
Jamison suggests that manic-depressive illness is in fact the expression of "malfunctions in a master biological clock". Her studies show pronounced seasonal patterns in productivity among writers and artists, confirmed by the biographies of many outstanding ones (Schumann composed over 130 songs in one year). It is quite likely that these creative periods coincide with swings of mood - particularly upwards - and that these in turn may coincide with seasonal changes in natural light.

If Jamison's general thesis is true, serious philosophical and ethical issues are involved, particularly now that better treatments are available for affective disorder. Most sufferers seek treatment today, even if it may dampen down their creativity, but those in the past, of course, had no such choice open to them. Jamison deals with the complex scientific issues in a vivid and readily intelligible way, only marred by occasional descent into Time-Life language and some diagnostic imperialism in assuming that the US system is the only one worth mentioning. These are minor blemishes, though, in an important work that should provoke some serious rethinking in several corners of academe.

Hugh Freeman is editor of the British Journal of Psychiatry, 17 Belgrave Square, London SW1X 8PG, UK.

\section{Our world in collision}

\section{Reinald Schröder}

Universal Ice: Science and Ideology in the Nazi State. By Robert Bowen. Belhaven: 1993. Pp. 189. £39.50. (US dist., St Martin's Press.)

NOWADAYS the name of Hörbiger evokes only the celebrated Viennese theatrical dynasty, especially its founders, the brothers Paul and Attila. It is less likely to bring to mind their father, Hanns, and his "World Ice Doctrine". Not so in Germany 50 years ago.

Robert Bowen, a geologist who concluded his academic training in Münster in 1991, has sought to rescue Hörbiger's cosmogony from oblivion, and in particular to discover how it was that this abstruse farrago of pseudoscience found so many adherents in the Third Reich, reaching indeed to the uppermost pinnacles of power. For they included Adolf Hitler and above all Heinrich Himmler.

Hanns Hörbiger (1860-1931) was a successful Austrian engineer, to whom the World Ice Doctrine came, late in the nineteenth century, "in bitter anguish of the spirit, as a vision"; its "cosmic, fathomless depths" threw his body into "feverish, shuddering spasms". Out of this experience Hörbiger drew his theory, which linked terrestrial and cosmic processes in a unifying drama of nature. In 1913, working with the amateur astronomer Philipp Fauth, he set down his cogitations in a book entitled Hörbiger's Glacial Cosmogony. Bowen's heroic endeavour has been to assimilate this barely readable work, comprising close on 800 pages of impenetrable gibberish, and boil down its message to a few dozen comprehensible pages. He has avoided unfair selectivity without sacrificing the perspective of a trained scientist.

According to Hörbiger then, the Mil- ky Way is made up of fragments of ice that lie outside the gravitational field of the Sun. When this veil of ice passes into the domain of the planetary system, it plunges into the Sun, melts and evaporates. Immense exploding funnels - the sunspots - eject mighty fountains of steam - the solar prominences - which instantly freeze to ice powder; this showers down on the inner planets, which thus acquire a thick glacial crust. The Moon itself has a coat of ice several kilometres thick. In the Earth's atmosphere the ice dust melts into rain, while larger lumps (meteors) burst and strike the Earth as hailstorms.

But it is not only ice that descends on the Sun and planets. The allencompassing ether slows the movement of all the heavenly bodies until they are trapped by the gravitational pull of the nearest inner planet and become moons, later to be absorbed by their planet. The planets are gradually approaching the Sun in spiral trajectories and will finally be drawn in and consumed. Our own planet too once possessed other moons, which crashed into the Earth, thus provoking natural catastrophes such as the immersion of Atlantis and Noah's Flood.

It is not surprising that a theory that scorns so many established facts and rests confessedly on nothing more than intuition and myth was rejected, or worse ignored, by the world of science. Hörbiger saw himself indeed in the line of Julius Robert Mayer, discoverer of conservation of energy, another unrecognized genius.

After this promising start, Bowen's book is a sad disappointment, for it tells us nothing new about the part played by the World Ice Doctrine in the history of the Third Reich. Readers have first to fight their way through a rather disjointed potpourri of German intellectual history in the 1920s and '30s. From Nietzsche on Wagner, the Mormons and the "Nazi philosopher" Heidegger, the text moves on to the campaign by the "Aryan physicists" (Lenard and Stark) against "Jewish physics" (quantum theory and relativity). The relation of all this to the World Ice Doctrine is left obscure; errors of fact accumulate (Fritz Strassmann, who worked with Otto Hahn on the discovery of nuclear fission, for instance, is given a posthumous Nobel prize), and standard works on the history of science in Germany at that time have not been cited, or, it seems, even consulted.

Nor do we learn how Hörbiger's theory influenced the Nazis. There are only a few pages in which it is related in detail that in 1937 a certain von Elmayer-Vestenbrugg, writing in a volume of the Kampfschriften der Obersten SA-Führung (Books of Struggle of the SA High Command) broke a lance for the World Ice Doctrine, commending this Nordic concept of the origins of the world and of natural catastrophes, so shamefully disregarded by the academics, as an appropriate Nazi ideol-

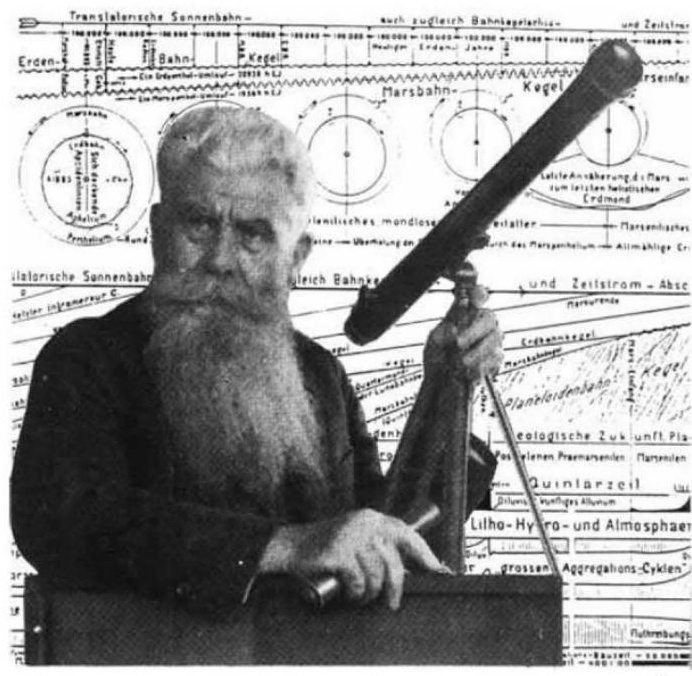

Hörblger and detall from his Glacial-Kosmogonie

ogy. Here Bowen unjustly accuses Hörbiger of embracing the ideology of the Nordic master race, for which there is no evidence in his writings. Neither does he reveal whether the SA author's article met with a favourable reception, or which members of the Nazi leadership declared for Hörbiger in consequence.

There is contradictory evidence in the literature as to whether Hitler was a follower of Hörbiger. It is certain only that he did not exert himself to promote the dissemination of Hörbiger's ideas. For Reichsführer SS Himmler, it was quite another matter: the studies of Brigitte Nagel (Die Welteislehre: Ihre Geschichte und ihre Rolle im "Dritten Reich", GNT, 1991) have exposed him as the highest-ranking supporter of the 